\title{
Next-generation calcineurin inhibitors in development for the prevention of organ rejection
}

This article was published in the following Dove Press journal:

Transplant Research and Risk Management

25 March 2014

Number of times this article has been viewed

\section{Osama Gheith \\ Torki Al-Otaibi \\ Hany Mansour}

Department of Nephrology, Hamed Al-Essa Organ Transplant Center, Ibn Sina Hospital, Shuwaikh, Kuwait
Correspondence: Osama Gheith Department of Nephrology, Hamed Al-Essa Organ Transplant Center, Ibn Sina Hospital, PO Box 25427, Safat, Shuwaikh I3II5, Kuwait Email ogheith@yahoo.com
Abstract: Calcineurin inhibitors (CNIs) remain the cornerstone of immunosuppression after renal transplantation despite their adverse effects. Some CNIs have well known negative impacts on the cardiovascular system, including hypertension, hyperlipidemia, new onset diabetes after transplantation (NODAT), neurotoxicity, hypertrichosis, and nephrotoxicity. Many clinical trials dealing with CNI avoidance or elimination were associated with higher risk of rejection of the transplanted organ. New generation CNIs are concerned with modifying CNI molecules so that they become more potent and are suitable for patients with suboptimal adherence with less adverse effects. In this review, we address these issues.

Keywords: calcineurin inhibitors, organ transplant, rejection

\section{Introduction}

Calcineurin inhibitors (CNIs) remain the cornerstone of immunosuppression after renal transplantation despite their adverse effects, which have a negative impact on the cardiovascular system. These side effects include hypertension, hyperlipidemia, new onset diabetes after transplantation (NODAT), neurotoxicity, hypertrichosis and nephrotoxicity. However, many clinical trials dealing with CNI avoidance or elimination are associated with higher risk of rejection of the transplanted organ. ${ }^{1-3}$

On the other hand, three different studies compared belatacept and cyclosporine (CsA) and all confirmed significantly better renal function among patients who received belatacept. ${ }^{4-6}$ Moreover, extended criteria donor (ECD) kidney transplant recipients who were treated with belatacept-based immunosuppression regimens achieved similar patient/graft survival, better renal function, and exhibited improvement in the cardiovascular/metabolic risk profile versus CsA-treated patients; however, there was an increased incidence of post-transplant lymphoproliferative disorder (PTLD). These differential findings might be explained by the use of CsA as the control group. Furthermore, head-to head studies have recognized better renal graft function in the tacrolimus (TAC) group compared to the CsA-based group. In the ELITE-Symphony study, the authors verified a significant advantage of TAC over CsA in estimated glomerular filtration rate (eGFR) preservation up to 3 years after transplantation. ${ }^{7}$

Compared to mycophenolate mofetil (MMF)/CNI treatment, a 2-year regimen of MMF and sirolimus (SRL) resulted in similar measures of renal function but with fewer deaths and a trend of less biopsy proven acute rejection (BPAR) and graft loss. ${ }^{8}$ Flechner ${ }^{9}$ reported that at 1-2 years of their study, the GFR was superior for the SRL group, with a loss of tolerability for about $20 \%$. Moreover, Shamseddin and Gupta, ${ }^{10}$ 
in a letter to the editor, questioned the sparing effect of SRL in the Spare-the-Nephron trial. ${ }^{11}$

CsA is cyclic, non-ribosomal peptide of fungal origin containing eleven amino acids including a single D-amino acid. It is used as an immunosuppressive agent for the prevention of solid-organ transplant rejection ${ }^{12}$ and in the treatment of autoimmune disorders, such as psoriasis. ${ }^{13}$

The main action of CsA is to inhibit the activity of T-cells and their immune response. It exerts this immunosuppressive effect through a cascade of actions when it combines with cyclophilin A forming a complex. Once this complex is formed, it will bind to and suppress intracelluler phosphatase $\mathrm{CN}$, which is followed by inhibition of activation of transcriptional activator 1 nuclear factor (by dephosphorylation) inside active T-cells and its subsequent translocation to the nucleus. Finally, the production of many cellular products, such as cytokines and lymphokines, will be blocked and the immune reaction is suppressed. ${ }^{14}$ Moreover, CNI can inhibit fibroblast proliferation and the release of other vascular growth factors related to endothelial growth. ${ }^{15-17}$

However, the chronic use of CsA is restricted due to its side effects, most notably nephrotoxicity. ${ }^{18,19}$ In an attempt to reduce such side effects, a modified CsA formulation has been generated with better bioavailability; nevertheless, it has more or less similar side effects. In a meta-analysis by Shah et al, ${ }^{20}$ which considered all published trials, they concluded that CsA (modified) is favored over CsA because of a lower rejection incidence and a trend towards less adverse events. However, when they limited their analysis to only randomized prospective trials (especially blinded studies) they found that CsA (modified) was associated with more adverse events. On the other hand, when analyzing open-labeled studies alone, they found that CsA was associated with more adverse events. Therefore, careful individual consideration must be given when choosing the best possible CsA formulation.

As a result of the continuous search for immunosuppressive agents with better efficacy and safety profiles, CsA derivative ISA247 (voclosporin; VCS) was successfully created. This was possible by studying the molecular structure of the CsA-CN complex and modifying the molecule to make it fit better against the hydrophobic $\mathrm{CN}$ surface, a property that increases its binding affinity with lower dosages and lower adverse effects. ${ }^{21}$

\section{VCS}

\section{Mechanism of action}

VCS is a novel CNI intended for the prevention of organ graft rejection and treatment of lupus nephritis. ${ }^{22}$ It has a strong immunosuppressant effect by reversible inhibition of
T-lymphocyte proliferation and release of cytokines through blocking the cytoplasmic calcium dependent phosphatase. ${ }^{15}$ Inside lymphocytes, voclosporin binds to immunophilins forming complexes that inhibit $\mathrm{CN}^{23,24}$ This scenario prevents translocation of the nuclear factor of active T-cells, followed by impairment of the transcription of genes encoding interleukin (IL)-2 and some other cellular products, especially lymphokines. ${ }^{16,23,24}$

Creation of VCS was carried out by changing the functional group on the amino acid residue at position one of the molecule, ${ }^{25}$ with more favorable pharmacokinetic properties compared to $\mathrm{CsA}^{26,27}$ and increased its immunosuppressive effects by nearly 4 -fold. ${ }^{28}$

Moreover, such a change in the molecule enhances the binding of the VCS-cyclophilin complex to $\mathrm{CN}$ receptors with faster elimination of its metabolites. Thus, increasing its potency and lowering the drug dose and its metabolites led to optimized kinetic and dynamic properties in addition to enhanced $\mathrm{CN}$ inhibition compared to the original component. $25,29,30$

Results of Phase I, II, and II clinical trials confirmed optimization of the pharmacokinetic/pharmacodynamic (PK/PD) properties of VCS. ${ }^{26,27}$ In continuation of such research work, initial systemic use of VCS in rats has been reported to be successful for the prevention and treatment of experimental autoimmune uveoretinitis. ${ }^{31}$

\section{Clinical trials with VCS}

In experimental animals (Table 1), Stalder et $\mathrm{al}^{32}$ found that VCS was more potent than CsA in suppressing T-cell function in monkeys. During initial studies, VCS has been evaluated among healthy volunteers. In single-dose studies, the dose ranged between 0.25 to $4.5 \mathrm{mg} / \mathrm{kg}$, while in multidoses studies, the dosage ranged between 0.25 to $1.5 \mathrm{mg} / \mathrm{kg}$ twice daily (bid). The drug showed good bioavailability, rapid absorption, and linear increases in the area under the curve (AUC) and maximum concentration $\left(\mathrm{C}_{\max }\right)$ with multiphasic elimination along 24 hours. In another study using multi-doses of VCS ranging between 0.25 to $0.5 \mathrm{mg} / \mathrm{kg}$ bid for a longer time period (10 days), the half-life $\left(\mathrm{T}_{1 / 2}\right)$ ranged between 6.9 to 7.8 hours and 30.1 to 33.2 hours on the first and thirteenth days, respectively. The authors confirmed potency of this new agent: nearly 4-fold compared to the original molecule (CsA) with accumulation up to the thirteenth day. Moreover, they found that VCS can inhibit $\mathrm{CN}$ in dose-proportional manner up to $1 \mathrm{mg} / \mathrm{kg}$ bid up to the tenth day after which inhibition plateaus. ${ }^{33}$ The use of such new agents for organ transplantation or autoimmune disorders as psoriasis has been 
Table I Summarizing most voclosporin clinical trials

\begin{tabular}{|c|c|c|c|c|c|}
\hline $\begin{array}{l}\text { Reference } \\
\text { number }\end{array}$ & Study phase & Patients & Duration & Dose & Conclusion \\
\hline Ling et $\mathrm{a}^{22}$ & $\begin{array}{l}\text { Phase II prospective, } \\
\text { parallel-group, open- } \\
\text { label trials }\end{array}$ & $\begin{array}{l}33 \text { renal cases; } \\
18 \text { hepatic patients }\end{array}$ & - & $0.4 \mathrm{mg} / \mathrm{kg}$ oral & $\begin{array}{l}\text { Mild to moderate hepatic impairment } \\
\text { resulted in a } 1.5 \text { - to } 2 \text {-fold increase } \\
\text { in voclosporin exposure; it can be } \\
\text { given to mild to moderate renal } \\
\text { impairment patients safely }\end{array}$ \\
\hline $\begin{array}{l}\text { Bissonnette } \\
\text { et } \mathrm{al}^{35}\end{array}$ & $\begin{array}{l}\text { Randomized, double- } \\
\text { blind, placebo-controlled, } \\
\text { parallel-group study }\end{array}$ & $\begin{array}{l}201 \text { plaque psoriasis } \\
\text { patients with }>10 \% \\
\text { body surface area } \\
\text { involvement }\end{array}$ & I2-week & $\begin{array}{l}0.5 \mathrm{mg} / \mathrm{kg} / \text { day, and } \\
1.5 \mathrm{mg} / \mathrm{kg} / \text { day in } \\
\text { two groups }\end{array}$ & $\begin{array}{l}\text { Voclosporin appears safe and effective } \\
\text { for treating moderate to severe } \\
\text { psoriasis }\end{array}$ \\
\hline Anglade et $\mathrm{al}^{33}$ & $\begin{array}{l}\text { Phase II/III prospective, } \\
\text { multicenter, double- } \\
\text { masked, placebo- } \\
\text { controlled, parallel-group, } \\
\text { randomized trials }\end{array}$ & $\begin{array}{l}\text { Randomized in a } 2: 2: 2: 1 \\
\text { ratio }\end{array}$ & $\begin{array}{l}\text { Patients } \\
\text { more than } \\
13 \text { years }\end{array}$ & $\begin{array}{l}\text { Voclosporin at a } \\
\text { dose of } 0.2,0.4 \text {, or } \\
0.6 \mathrm{mg} / \mathrm{kg} \text { bid, or } \\
\text { placebo }\end{array}$ & $\begin{array}{l}\text { Voclosporin could represent a new } \\
\text { standard of care offering hope for } \\
\text { patients with this uveitis }\end{array}$ \\
\hline Dumont $F^{25}$ & $\begin{array}{l}\text { I2-week, randomized, } \\
\text { multicenter, open-label } \\
\text { study }\end{array}$ & $\begin{array}{l}\text { I32 stable kidney } \\
\text { transplants } \\
\text { (cyclosporine A switch } \\
\text { to voclosprine) }\end{array}$ & 12 weeks & & $\begin{array}{l}\text { Good bioavailability, rapid } \\
\text { absorption, and less drug exposure }\end{array}$ \\
\hline Yatscoff ${ }^{26}$ & $\begin{array}{l}\text { Phase II studies in renal } \\
\text { transplant patients }\end{array}$ & $\begin{array}{l}\text { Stable kidney } \\
\text { transplant cases }\end{array}$ & & & $\begin{array}{l}\text { Optimization of the pharmacokineticl } \\
\text { pharmacodynamic properties; } \\
\text { drug efficacy and tolerability were } \\
\text { confirmed }\end{array}$ \\
\hline $\begin{array}{l}\text { Gaston et } \mathrm{al}^{37} \\
\text { and } \\
\text { Busque et } \mathrm{al}^{38}\end{array}$ & $\begin{array}{l}\text { Randomized, open-label, } \\
\text { Phase IIB trial }\end{array}$ & $\begin{array}{l}\text { I16 patients for } \\
\text { comparing voclosporin } \\
\text { and tacrolimus }\end{array}$ & 4 months & $\begin{array}{l}\text { Voclosporin in doses } \\
\text { of } 0.4,0.6 \text {, and } \\
0.8 \mathrm{mg} / \mathrm{kg} \text { bid and } \\
\text { tacrolimus in a dose } \\
\text { of } 0.05 \mathrm{mg} / \mathrm{kg} \text { bid }\end{array}$ & Similar efficacy and less diabetogenic \\
\hline Busque et $\mathrm{al}^{39}$ & $\begin{array}{l}\text { Multicenter, randomized, } \\
\text { open-label study } \\
\text { (PROMISE) }\end{array}$ & $\begin{array}{l}334 \text { low risk kidney } \\
\text { transplants }\end{array}$ & 6 months & $\begin{array}{l}\text { Three ascending } \\
\text { concentration- } \\
\text { controlled groups of } \\
\text { voclosporin compared } \\
\text { to tacrolimus }\end{array}$ & $\begin{array}{l}\text { Voclosporin is as efficacious as } \\
\text { tacrolimus in preventing acute } \\
\text { rejection with similar renal function } \\
\text { in the low and medium-exposure } \\
\text { groups, and potentially associated } \\
\text { with a reduced incidence of new } \\
\text { onset diabetes after transplantation }\end{array}$ \\
\hline Gupta $^{44}$ & $\begin{array}{l}\text { Randomized double-blind } \\
\text { placebo-controlled study }\end{array}$ & $\begin{array}{l}\text { Patients with plaque } \\
\text { psoriasis }\end{array}$ & & Different doses & $\begin{array}{l}\text { Optimization of voclosporin dosages } \\
\text { in relation to calcineurin inhibition }\end{array}$ \\
\hline Papp et al ${ }^{48}$ & $\begin{array}{l}\text { A randomized, } \\
\text { multicenter, double- } \\
\text { blind, placebo controlled } \\
\text { Phase III study }\end{array}$ & $\begin{array}{l}336 \text { patients with } \\
\text { plaque psoriasis }\end{array}$ & 3 months & $\begin{array}{l}0.2,0.3 \text {, or } 0.4 \mathrm{mg} / \mathrm{kg} \\
\text { twice daily }\end{array}$ & $\begin{array}{l}\text { Relatively mild nephrotoxic nature } \\
\text { of this molecule; reductions in } \\
\text { glomerular filtration rate were seen } \\
\text { in } 2 \% \text { of patients }\end{array}$ \\
\hline Stalder et $\mathrm{a}^{32}$ & Animal study & $\begin{array}{l}16 \text { monkeys comparing } \\
\text { cyclosporine with } \\
\text { voclosporin }\end{array}$ & I week & 25 and $50 \mathrm{mg} / \mathrm{kg} /$ day & $\begin{array}{l}\text { Voclosporin is more potent than } \\
\text { cyclosporine in suppressing T-cell } \\
\text { function }\end{array}$ \\
\hline
\end{tabular}

Abbreviation: bid, twice daily.

reported to be successful, suggesting a possible role for it in the treatment of other autoimmune disorders.

Cytochrome P450 (CYP450) 3A4/5 acts as the primary enzyme involved in the initial phase of VCS metabolism. With extensive first-pass hepatic metabolism the drug will be hydroxylated and demethylated into active metabolites. ${ }^{33,34}$ VCS can inhibit the activity of CYP450 3A4, but not CYP2D6 or CYP2C9. VCS should be taken without food for better absorption to ensure adequate drug concentration.
Moreover, animal studies showed that the primary route of excretion is through the gut. ${ }^{33}$

For further assessment of this new drug, a randomized, multicenter, open-label study Phase IIA study for 12-weeks involving 132 stable renal transplant recipients who were switched from CsA (modified) to VCS was undertaken. Acute rejection was considered as primary endpoint of the study. ${ }^{25,26}$ VCS generated an immunosuppressive effect that was comparable to CsA (modified) at $33 \%$ of the blood drug 
level. In addition, they found strong correlations between the concentration of drug in plasma after 12 hours and immediately before the morning dose $\left(\mathrm{C}_{0}\right)$ and both $\mathrm{AUC}$ and level of CN inhibition by VCS; a correlation that was lacking with CsA (modified).

Similarly, in another conversion study concerning stable renal transplant patients, VCS drug efficacy and tolerability were confirmed. ${ }^{25}$ Moreover, in Phase II/III studies using VCS among patients with other autoimmune disorders - namely plaque psoriasis - the authors confirmed its efficacy with minimal nephrotoxicity. ${ }^{34-36}$

To compare the efficacy and safety of VCS versus TAC among de novo renal transplant recipients, Gaston et $\mathrm{al}^{37}$ completed a randomized, open-label, Phase IIB trial. They started VCS in doses of $0.4,0.6$, and $0.8 \mathrm{mg} / \mathrm{kg}$ bid and TAC in a dose of $0.05 \mathrm{mg} / \mathrm{kg}$ bid, and optimized the doses according to target trough concentrations. Among the first 116 patients who completed up to 4 months of therapy (range, $3.7 \pm 2.2$ to $4.5 \pm 2.2$ months), Busque et $\mathrm{al}^{38}$ found that the two agents have similar efficacy, as measured by the number of biopsy-proven acute rejection episodes. Moreover, renal graft function was good in all patients who were managed by VCS regardless the dosage used. ${ }^{38}$

In the PROMISE study, Busque et $\mathrm{al}^{39}$ compared the results of VCS versus TAC in renal transplant recipients after 6 months of transplantation. They found that it has the ability to prevent acute rejection more or less equally to TAC, with fewer incidences of NODAT. They added that cases that were exposed to low and medium doses of VCS showed similar renal function with a clear PK/PD relationship. ${ }^{39}$ Moreover, they found no significant difference between eGFR among these two groups and the TAC control group $(68 \mathrm{~mL} / \mathrm{minute}$ versus $69 \mathrm{~mL} /$ minute, $P<0.05$ ). Such data suggest a potential upper limit of exposure associated with renal function. In addition, in the same study, the authors found that VCS demonstrated an excellent correlation between trough level of the drug and its area under the curve $\left(r^{2}=0.97\right)$ and found no difference in mycophenolic acid (MPA) exposure compared to TAC. Similarly, both Busque et $\mathrm{al}^{4}$ and Vincenti et $\mathrm{al}^{40}$ reported a clear relationship between VCS exposure, degree of $\mathrm{CN}$ inhibition, and risk of acute rejection. They added that acute rejection rates were equivalent to recent studies utilizing new immunosuppressant drug with tremendous renal function in all treatment groups with eGFR around $70 \mathrm{~mL} /$ minute.

CsA is recognized to be less diabetogenic than TAC; 40 however, both agents interfere with the $\mathrm{CN}$ nuclear factor of the active T-cell signaling pathway, which is needed for insulin secretion and islet physiology. ${ }^{41}$
Øzbay et $\mathrm{al}^{42}$ used retrospective Kaplan-Meier estimates of biopsy proven acute rejection and post-transplant diabetes according to the 2003 American Diabetes Association (ADA) guidelines among $28 \mathrm{VCS}$ treated patients. These patients were exposed to trough levels within the range planned for future assessment ( 35 to less than $60 \mathrm{ng} / \mathrm{mL}$ ), and they compared data with the TAC treated group; they found no significant difference between the two groups $(P>0.05)$. They added that the two drugs might be different, but TAC reduces insulin secretion earlier than $\mathrm{CsA}$. They found that the incidence of NODAT increased with higher exposure to VCS - as seen in the high-dose group - with a similar incidence as the TAC group. However, the number of VCS-treated patients with NODAT required less anti-diabetic treatment than the TAC-treated patients. Therefore, they concluded that VCS may be similar to CsA with respect to its diabetogenicity. However, the high level of VCS exposure associated with higher incidence of NODAT similar to TAC may not be needed for adequate rejection prophylaxis.

Vincenti et $\mathrm{al}^{5}$ and Busque et $\mathrm{al}^{4}$ had reported that adverse effects were generally similar between VCS and TAC treatment groups. However, they observed more diarrhea among TAC treated patients with continuation of neurological symptoms - especially tremors - beyond the third month after transplantation. Regarding common CsA adverse effects, such as hypertension, hyperlipidemia, and gingival hyperplasia, they found no significant difference between TAC and VCS; however, they reported mild and infrequent hypertrichosis among VCS cases. The authors added that in spite of the fact that their studies were relatively short-term in nature, VCS was not associated with an increased incidence of infections or post-transplant lymphoma as seen with studies concerning other new immunosuppressives.

The PK and PD evaluation performed in PROMISE indicates that VCS trough level monitoring can be a tremendous marker of drug exposure and $\mathrm{CN}$ inhibition. It does not reduce MPA exposure (simulating TAC, in contrary to CsA) when combined with MMF. ${ }^{43}$ Post hoc analyses of VCS trough exposure were performed to evaluate clinical outcomes in all patients on VCS therapy to determine the optimal exposure that minimizes both rejection and NODAT in such cases. It was observed that NODAT incidence of more than $8 \%$ would be seen with higher VCS levels than $60 \mathrm{ng} / \mathrm{mL}$, while BPAR would be associated with a significantly lower $(<35 \mathrm{ng} / \mathrm{mL})$ exposure. Moreover, BPAR was seen in the low and mid-dose groups after the third month of mandatory exposure reduction that was associated with trough levels $<30 \mathrm{ng} / \mathrm{mL}$. On the other hand, the high dose group remained free of rejection 
with an exposure more than $31 \mathrm{ng} / \mathrm{mL}$. They concluded that a VCS target range between 35 to $<60 \mathrm{ng} / \mathrm{mL}$ may result in comparable rejection rates and nearly $50 \%$ the rate of NODAT seen in TAC group. However, the limitations of this study include the enrollment of patients at relatively low risk for rejection and no delayed graft function, and therefore the results observed may not be applicable to all renal transplant recipients. Moreover, the TAC levels were higher than in the ELITE-Symphony study and protocol biopsies were not performed to assess the impact of different VCS exposures on the development of interstitial fibrosis and tubular atrophy. ${ }^{5}$

Gupta et $\mathrm{a}^{44}$ studied the PK and PD of VCS in a Phase III, randomized, placebo-controlled, multicenter, double-blind study and they concluded that its concentration was highly correlated with $\mathrm{CN}$ inhibition $(r=0.79)$, and the percentage of that inhibition was highly correlated with mean percent reduction in the efficacy endpoint $(r=0.86)$. Based on these data, Bissonnette et $\mathrm{al}^{35}$ concluded that VCS appears safe and effective for treating moderate to severe psoriasis.

\section{VCS safety}

In view of VCS tolerability and safety in all initial trials in doses up to $4.5 \mathrm{mg} / \mathrm{kg}$, evolution of trials had been progressed to Phase II and III trials among renal transplant recipients and patients with psoriasis. ${ }^{21,25,28,35,44,45}$ In such trials, some side effects, such as headache, diarrhea, and hypertension were reported. ${ }^{26,35,44}$ Such adverse effects appear to be dosedependent. To date, most studies do not show any significant changes in lipid profiles represented by serum levels of cholesterol, triglycerides, other biochemical parameters, NODAT, or infectious complications.

Regarding renal function, most patients enrolled in all studies had stable renal graft function, which was assessed by creatinine clearance. Moreover, in a Phase III study in psoriasis patients, the highest mean change in serum creatinine in any dosing group $(0.2,0.3$, or $0.4 \mathrm{mg} / \mathrm{kg}$ bid $)$ at week 12 was $5.6 \%$ above baseline, which was considered to be within normal physiological variation. ${ }^{46}$

In a small study including 100 patients, the drug was withdrawn due to a clinically significant decrease in kidney function $(4 \%$ in the high VCS dose and $1 \%$ in the middose group). However, at 24 weeks there were no clinically significant changes in mean serum creatinine or GFR, but five patients withdrew due to a $30 \%$ reduction in GFR. ${ }^{47}$ After 60 weeks of follow up, mean renal function represented by serum creatinine remained stable. Nevertheless, significant changes in renal function developed in $4 \%$ of patients.

\section{VCS therapeutic monitoring}

The data derived from safety studies suggested a broader therapeutic window of VCS in contrary to other CNIs, such as $\mathrm{CsA}$ and TAC, which required drug monitoring to correlate the parent substance and its metabolites with other clinical parameters. ${ }^{48,49}$ Within the therapeutic range of inhibition of CN (40\% to $70 \%)$, VCS showed no significant changes in mean creatinine clearance, mean arterial blood pressure, or serum magnesium levels. Deleterious effects of VCS on creatinine clearance has only been observed when $\mathrm{CN}$ inhibition is more than $70 \% .{ }^{50}$ Similarly, other data indicate that $40 \% \mathrm{CN}$ inhibition is achieved with VCS at an AUC of $226 \mathrm{ng} \times$ hour $/ \mathrm{mL}$, but with a $15 \%$ rise in serum creatinine occurs only at a VCS AUC of $3448 \mathrm{ng} \times$ hour $/ \mathrm{mL} .^{22,50}$

Ling et $\mathrm{al}^{22}$ concluded that mild to moderate hepatic impairment resulted in a 1.5- to 2-fold increase in VCS exposure. VCS can be administered safely to patients with mild to moderate renal impairment without dose modification. Appropriate safety monitoring with concentration-based adjustments in transplantation are recommended for patients with severe renal impairment and for patients with hepatic impairment.

\section{New trends in other CNIs}

Advagraf $^{\circledR}$ (Astellas Pharma US, Inc, Way Northbrook, IL, USA) is a new slow release form of TAC with a once-daily formulation, which has the potential advantage of better adherence and a safer profile by avoiding toxic peak concentrations. Yatscoff et al ${ }^{51}$ found a significant decrease in TAC exposure after switching to Advagraf. Therefore, they recommend that switching from TAC to Advagraf should be performed under close medical supervision. Moreover, Carcas-Sansuán et al showed that Advagraf bioequivalence cannot be ensured in pediatric populations and they found significant changes in TAC levels and dose on long-term follow-up. ${ }^{52}$ Tanaka et $\mathrm{al}^{53}$ and Carcas Sunsuan et $\mathrm{al}^{54}$ reported that conversion from TAC to Advagraf in live donor liver transplants can be performed safely and effectively without affecting liver, renal, and immune functions. Wu et $\mathrm{al}^{55}$ concluded that the policy of converting to Advagraf with the purpose of improving medical adherence should be individualized in routine clinical practice. Moreover, among patients who represented the European kidney transplant population - the OSAKA trial - they found that TAC once per day (QD)-based immunosuppression $(0.2 \mathrm{mg} / \mathrm{kg} /$ day $)$, without induction, showed similar efficacy to $0.2 \mathrm{mg} / \mathrm{kg}$ per day TAC twice per day. ${ }^{56}$

Although Carcas-Sansuán et $\mathrm{al}^{57}$ reported that conversion from TAC to Advagraf with a 1:1 dose equivalence is appropriate as an initial guideline, a 1-year follow-up showed a 
transient reduction in TAC levels that requires closer monitoring of drug levels post-conversion. To overcome this problem, Ma et $\mathrm{al}^{58}$ found that conversion from TAC to Advagraf in renal allograft recipients with or without diltiazem co-treatment required an increase in the daily dose by nearly $30 \%$ to maintain the target blood trough level. Similarly, Ghodsizad et $\mathrm{al}^{59}$ suggested that Advagraf is a safe alternative to Prograf ${ }^{\circledR}$ (Astellas Pharma US, Inc.) for patients who have undergone heart transplantation; trough levels were comparable after an adjustment period and there were no differences between the two groups with respect to their 1-year mortality rates. Furthermore, Kuypers et $\mathrm{al}^{60}$ reported that TAC once daily is significantly superior to the bid regimen that overcomes the residual prevalence of suboptimal adherence that will have to be countered by means other than reformulation and regimen simplification.

\section{Conclusion}

Much effort is being expended to create a newer generation of CNIs for the prevention of organ rejection and to avoid adverse effects. Volcosporin is a more potent promising immunosuppressive agent with fewer side effects than CsA while Advagraf is comparable to TAC especially in patients with suboptimal adherence; however, Advagraf requires close monitoring of levels until it reaches therapeutic significance.

\section{Disclosure}

The authors report no conflicts of interest in this paper.

\section{References}

1. Ekberg H, Grinyó J, Nashan B, et al. Cyclosporine sparing with mycophenolate mofetil, daclizumab and corticosteroids in renal allograft recipients: the CAESAR Study. Am J Transplant. 2007;7(3):560-570.

2. Johnson RW, Kreis H, Oberbauer R, Brattström C, Claesson K, Eris J. Sirolimus allows early cyclosporine withdrawal in renal transplantation resulting in improved renal function and lower blood pressure. Transplantation. 2001;72(5):777-786.

3. Larson TS, Dean PG, Stegall MD, et al. Complete avoidance of calcineurin inhibitors in renal transplantation: a randomized trial comparing sirolimus and tacrolimus. Am J Transplant. 2006;6(3):514-522.

4. Busque S, Leventhal J, Brennan DC, et al. Calcineurin-inhibitorfree immunosuppression based on the JAK inhibitor CP-690,550: a pilot study in de novo kidney allograft recipients. Am J Transplant. 2009;9(8):1936-1945.

5. Vincenti F, Charpentier B, Vanrenterghem Y, et al. A phase III study of belatacept-based immunosuppression regimens versus cyclosporine in renal transplant recipients (BENEFIT study). Am J Transplant. 2010;10(3):535-546.

6. Durrbach A, Pestana JM, Pearson T, et al. A phase III study of belatacept versus cyclosporine in kidney transplants from extended criteria donors (BENEFIT-EXT study). Am J Transplant. 2010;10(3):547-557.

7. Ekberg H, Bernasconi C, Tedesco-Silva H, et al. Calcineurin inhibitor minimization in the Symphony study: observational results 3 years after transplantation. Am J Transplant. 2009;9(8):1876-1885.
8. Weir MR, Mulgaonkar S, Chan L, et al. Mycophenolate mofetil-based immunosuppression with sirolimus in renal transplantation: a randomized, controlled Spare-the-Nephron trial. Kidney Int. 2011;79(8): 897-907.

9. Flechner SM. Can the nephron be spared? Kidney Int. 2011;79(8): 804-806.

10. Shamseddin MK, Gupta A. Sirolimus: not so sparing in the Spare-theNephron trial. Kidney Int. 2011;79(12):1379; author reply 1379-1380.

11. Teperman L, Moonka D, Sebastian A, et al. Spare-the-Nephron Trial Liver Transplantation Study Group. Calcineurin inhibitor-free mycophenolate mofetil/sirolimus maintenance in liver transplantation: the randomized spare-the-nephron trial. Liver Transpl. 2013;19(7):675-689.

12. Graeb C, Arbogast H, Guba M, Jauch KW, Land W. Cyclosporine: 20 years of experience at the University of Munich. Transplant Proc. 2004;36(2):125S-129S.

13. Sobell JM, Hallas SJ. Systemic therapies for psoriasis: understanding current and newly emerging therapies. Semin Cutan Med Surg. 2003;22(3):187-195.

14. Hamawy MM. Molecular actions of calcineurin inhibitors. Drug News Perspect. 2003;16(5):277-282.

15. Dumont FJ. Cyclosporine A and tacrolimus (FK-506) immunosuppression through immunophilin-dependent inhibition of calcineurin function. In: Lieberman R, Mukherjee A, editors. Principles of Drug Development in Transplantation and Autoimmunity. New York: Chapman and Hall; 1996;1:175-205.

16. Ho S, Clipstone N, Timmermann L, et al. The mechanism of action of cyclosporin A and FK506. Clin Immunol Immunopathol. 1996; 80(3 Pt 2):S40-S45.

17. Cho ML, Cho CS, Min SY, et al. Cyclosporine inhibition of vascular endothelial growth factor production in rheumatoid synovial fibroblasts. Arthritis Rheum. 2002;46(5):1202-1209.

18. Burdmann EA, Andoh TF, Yu L, Bennett WM. Cyclosporine nephrotoxicity. Semin Nephrol. 2003;23(5):465-476.

19. Serkova NJ, Christians U, Benet LZ. Biochemical mechanisms of cyclosporine neurotoxicity. Mol Interv. 2004;4(2):97-107.

20. Shah MB, Martin JE, SchroederTJ, First MR. The evaluation of the safety and tolerability of two formulations of cyclosporine: neoral and sandimmune. A meta-analysis. Transplantation. 1999;67(11):1411-1417.

21. Aspeslet L, Freitag D, Trepanier D, et al. ISA(TX)247 a novel calcineurin inhibitor. Transplant Proc. 2001;33(1-2):1048-1051.

22. Ling SY, Huizinga RB, Mayo PR, Freitag DG, Aspeslet LJ, Foster RT. Pharmacokinetics of voclosporin in renal impairment and hepatic impairment. J Clin Pharmacol. 2013;53(12):1303-1312.

23. Schreiber SL, Crabtree GR. The mechanism of action of cyclosporin A and FK506. Immunol Today. 1992;13(4):136-142.

24. Stalder M, Bîrsan T, Hubble RW, Paniagua RT, Morris RE. In vivo evaluation of the novel calcineurin inhibitor ISATX247 in non-human primates. J Heart Lung Transplant. 2003;22(12):1343-1352.

25. Dumont FJ. ISAtx-247 (Isotechnika/Roche). Curr Opin Investig Drugs. 2004;5(5):542-550.

26. Yatscoff R, Abel M, Aspeslet L, et al. Phase 2 randomized, multicenter, open-label study of ISA247 and Neoral in post-renal transplant patients. Am J Transplant. 2003;5:463. Abstract.

27. Wasel N, Gupta A, Tomi Z, et al. Pharmacokinetics and pharmacodynamics of ISA247 in a Phase III randomized, multicenter, double-blind, placebo-controlled study. J Am Acad Dermatol. 2006; 54(Suppl 1):P36. Abstract.

28. Aspeslet L, Freitag D, Huizinga RB, et al. Pharmacokineticspharmacodynamics and safety of Trans-ISA247: A novel immunosuppressant. Poster presented at: Proceedings of the 3rd International Congress on Immunosuppression; December 8-11, 2004; San Diego, CA: 150367.

29. Abel MD, Aspeslet LJ, Freitag DG, et al. ISATX247: a novel calcineurin inhibitor. J Heart Lung Transplant. 2001;20(2):161.

30. Bîrsan T, Dambrin C, Freitag DG, Yatscoff RW, Morris RE. The novel calcineurin inhibitor ISA247: a more potent immunosuppressant than cyclosporine in vitro. Transpl Int. 2005;17(12):767-771. 
31. Cunningham MA, Li Z, Chan CC, et al. Subcutaneous injections of LX211 prevent and reverse experimental autoimmune uveoretinitis in rats. Proceedings of the Association for Research in Vision and Ophthalmology Annual Meeting; May 6-10, 2007; Fort Lauderdale, FL: B730.

32. Stalder M, Bîrsan T, Hubble RW, Paniagua RT, Morris RE. In vivo evaluation of the novel calcineurin inhibitor ISATX247 in non-human primates. J Heart Lung Transplant. 2003;22(12):1343-1352.

33. Anglade E, Aspeslet LJ, Weiss SL. A new agent for the treatment of noninfectious uveitis: rationale and design of three LUMINATE (Lux Uveitis Multicenter Investigation of a New Approach to Treatment) trials of steroid-sparing voclosporin. Clin Ophthalmol. 2008;2(4):693-702.

34. Freitag D, Mayo P, Aspeslet L, et al. The novel immunosuppressant ISA247 demonstrates a different metabolic profile than cyclosporine A in vitro and in vivo. Proceedings of the World Transplant Congress; July 22-27, 2006; Boston, MA: 2434.

35. Bissonnette R, Papp K, Poulin Y, et al; ISA247 Psoriasis Study Group. A randomized, multicenter, double-blind, placebo-controlled phase 2 trial of ISA247 in patients with chronic plaque psoriasis. $J$ Am Acad Dermatol. 2006;54(3):472-478.

36. Papp K, Bissonnette R, Rosoph L, et al. Efficacy of ISA247 in plaque psoriasis: a randomised, multicentre, double-blind, placebo-controlled phase III study. Lancet. 2008;371(9621):1337-1342.

37. Gaston R, Busque S, Cantarovich M, et al. for the PROMISE Study Investigators. ISA247: A novel calcineurin inhibitor (CNI). A promising safety profile with enhanced efficacy [poster]. Proceedings of the American Society of Nephrology,; San Diego, CA, USA. 2006. Clin Ophthalmol. 2008 December; 2(4): 693-702. Published online 2008 December. PMCID: PMC2699819A new agent for the treatment of noninfectious uveitis: rationale and design of three LUMINATE (Lux Uveitis Multicenter Investigation of a New Approach to Treatment) trials of steroid-sparing voclosporin.

38. Busque S, Laftavi M, Gaston R, et al. ISA247: Preliminary results of a phase IIb multicentre, de novo renal transplant trial. Abstract presented at: Proceedings of the American Transplant Congress; May 6, 2007; San Francisco, CA: 49. Clin Ophthalmol. 2008 December; 2(4): 693-702. Published online 2008 December. PMCID: PMC2699819 A new agent for the treatment of noninfectious uveitis: rationale and design of three LUMINATE (Lux Uveitis Multicenter Investigation of a New Approach to Treatment) trials of steroid-sparing voclosporin.

39. Busque S, Cantarovich M, Mulgaonkar S, et al; PROMISE Investigators. The PROMISE study: a phase 2b multicenter study of voclosporin (ISA247) versus tacrolimus in de novo kidney transplantation. Am J Transplant. 2011;11(12):2675-2684.

40. Vincenti F, Larsen C, Durrbach A, et al; Belatacept Study Group. Costimulation blockade with belatacept in renal transplantation. $N$ Engl J Med. 2005;353(8):770-781.

41. Vincenti F, Friman S, Scheuermann E, et al; DIRECT (Diabetes Incidence after Renal Transplantation: Neoral C Monitoring Versus Tacrolimus) Investigators. Results of an international, randomized trial comparing glucose metabolism disorders and outcome with cyclosporine versus tacrolimus. Am J Transplant. 2007;7(6):1506-1514.

42. Øzbay LA, Smidt K, Mortensen DM, Carstens J, Jørgensen KA, Rungby J. Cyclosporin and tacrolimus impair insulin secretion and transcriptional regulation in INS-1E beta-cells. Br J Pharmacol. 2011;162(1):136-146.

43. Heit JJ, Apelqvist AA, Gu X, et al. Calcineurin/NFAT signalling regulates pancreatic beta-cell growth and function. Nature. 2006;443(7109): 345-349.

44. Gupta A, Tomi Z, Kunynetz R, et al. Pharmacokinetics and pharmacodynamics of ISA247 in a Phase III, randomized, multicentre, doubleblind, placebo-controlled study. Abstract presented at: The Canadian Dermatology Association 81st Annual Conference; June 27-July 2, 2006; Winnipeg, Manitoba.

45. Grinyó JM, Ekberg H, Mamelok RD, et al. The pharmacokinetics of mycophenolate mofetil in renal transplant recipients receiving standard-dose or low-dose cyclosporine, low-dose tacrolimus or lowdose sirolimus: the Symphony pharmacokinetic substudy. Nephrol Dial Transplant. 2009;24(7):2269-2276.
46. Isotechnika, Inc. [Accessed July 8, 2007]; Phase 3 Canadian Psoriasis Study. 2007b URL: http://www.isotechnika.com/in_development/ isa247/psoriasis.

47. Langley R, Bissonnette R, Searles G, et al. 24 Week results of a Phase III randomized, double-blind, multicentre, placebo-controlled study of ISA247 in plaque psoriasis. Abstract presented at: The Canadian Dermatology Association 81st Annual Conference; June 27-July 2, 2006; Winnipeg, Manitoba.

48. Papp K, Langley R, Bissonnette R, et al. A Phase III, randomized, multicenter, double-blind, placebo-controlled study of ISA247 in plaque psoriasis patients. J Am Acad Dermatol. 2004;54(Suppl 1):P33. Abstract.

49. Staatz CE, Tett SE. Clinical pharmacokinetics and pharmacodynamics of tacrolimus in solid organ transplantation. Clin Pharmacokinet. 2004;43(10):623-653.

50. Vollenbroeker B, Koch JH, Fobker M, Suwelack B, Hohage H, Müller U. Determination of cyclosporine and its metabolites in blood via HPLC-MS and correlation to clinically important parameters. Transplant Proc. 2005;37(4):1741-1744.

51. Yatscoff RW, Broski AP, Abel MD, et al. Phase 2 trial results of ISATX247, a novel calcineurin inhibitor with a therapeutic window. Abstract presented at: Proceedings of the IXI International Congress of The Transplantation Society; April 29, 2002; Miami, FL: 0471 .

52. Hougardy JM, Broeders N, Kianda M, et al. Conversion from Prograf to Advagraf among kidney transplant recipients results in sustained decrease in tacrolimus exposure. Transplantation. 2011;91(5): 566-569.

53. Tanaka T, Takatsuki M, Soyama A, et al. Evaluation of immune function under conversion from Prograf to Advagraf in living donor liver transplantation. Ann Transplant. 2013;18:293-298.

54. Carcas-Sansuán AJ, Espinosa-Román L, Almeida-Paulo GN, et al. Conversion from Prograf to Advagraf in stable paediatric renal transplant patients and 1-year follow-up. Pediatr Nephrol. 2014;29(1):117-123.

55. Wu SW, Tsai HC, Tsai PY, Hung TW, Chang HR, Lian JD. Conversion to prolonged release tacrolimus formulation in stable kidney transplant recipients. Swiss Med Wkly. 2013;143:w13850.

56. Albano L, Banas B, Klempnauer JL, Glyda M, Viklicky O, Kamar N; Optimising immunoSuppression After Kidney transplantation with ADVAGRAF (OSAKA) study group. OSAKA Trial: A Randomized, Controlled Trial Comparing Tacrolimus QD and BD in Kidney Transplantation. Transplantation. 2013;96(10): 897-903.

57. Carcas-Sansuán AJ, Hierro L, Almeida-Paulo GN, et al. Conversion from Prograf to Advagraf in adolescents with stable liver transplants: comparative pharmacokinetics and 1-year follow-up. Liver Transpl. 2013;19(10):1151-1158.

58. Ma MK, Kwan LP, Mok MM, Yap DY, Tang CS, Chan TM. Significant reduction of Tacrolimus trough level after conversion from twice daily Prograf to once daily Advagraf in Chinese renal transplant recipients with or without concomitant diltiazem treatment. Ren Fail. 2013;35(7):942-945.

59. Ghodsizad A, Koch A, Ungerer MN, et al. Immunosuppression with tacrolimus early after orthotopic heart transplantation: a comparison of prograf and advagraf. Heart Surg Forum. 2012;15(6): E307-E309.

60. Kuypers DR, Peeters PC, Sennesael JJ, et al; ADMIRAD Study Team. Improved adherence to tacrolimus once-daily formulation in renal recipients: a randomized controlled trial using electronic monitoring. Transplantation. 2013;95(2):333-340. 


\section{Publish your work in this journal}

Transplant Research and Risk Management is an international, peerreviewed open access journal focusing on all aspects of transplantation and risk management to achieve optimal outcomes in the recipient improving survival and quality of life. The journal welcomes submitted papers covering original research, basic science, clinical studies,

reviews \& evaluations, guidelines, expert opinion and commentary, case reports and extended reports. The manuscript management system is completely online and includes a very quick and fair peer-review system, which is all easy to use. Visit http://www.dovepress.com/ testimonials.php to read real quotes from published authors.

Submit your manuscript here: http://www.dovepress.com/transplant-research-and-risk-management-journal 